\title{
Lateral
}

Journal of the Cultural Studies Association

\section{Review of Disruptive Situations: Fractal Orientalism and Queer Strategies in Beirut by Ghassan Moussawi (Temple University Press)}

\author{
by Robert Flahive | Book Reviews, Issue 10.1 (Spring 2021).
}

\begin{abstract}
Ghassan Moussawi's Disruptive Situations challenges the exceptionalist representations of lesbian, gay, bisexual, and trans (LGBT) experiences in Beirut through a focus on the everyday queer strategies and tactics. Moussawi analyzes the everyday practices of LGBT interlocutors navigating al-wad' (the situation), a term that refers to the normative order of disruptions, precarity, and instability that permeate daily life across contemporary Beirut. Al-wad' simultaneously features as a historical condition of perpetual instability bearing on daily life in Beirut, as well as a lens to analyze the practices of everyday life for Moussawi's LGBT interlocutors. Moussawi's inductive ethnographic approach charts the strategic use of identities, visibility, and "bubbles" or sources of solace in order to challenge exceptionalist representations of Beirut and LGBT experiences in the city. Moussawi critiques these reductive representations as "fractal orientalism", a reductive representation that embeds hierarchies and exclusion through geographic associations, such as in fashioning Beirut as the "Paris of the Middle East". Beirut becomes charming and "cosmopolitan" in a way that is similar to, but not quite, the same as Paris. Moussawi's focus on queer daily practices against the backdrop of al-wad' shows the limitations of these reductive representations in an effort to reimagine queerness, subjectivity, and politics.
\end{abstract}

KEYWORDS Beirut, gender, queer, sexuality

Disruptive Situations: Fractal Orientalism and Queer Strategies in Beirut. By Ghassan Moussawi. Philadelphia, PA: Temple University Press, 2020, 210 pp. (ebook) ISBN 978-1-4399-18517. US List: \$29.95.

In Disruptive Situations: Fractal Orientalism and Queer Strategies in Beirut, Ghassan Moussawi inverts the premise at the core of queer theory of disrupting a normative position by inquiring into the normative social condition of perpetual disruption that marks daily life in Beirut. In other words, "living amid an already queer situation means that everyday-life strategies of survival in Beirut are queer" (79, italics in original).

Moussawi's inversion centers the everyday queer strategies and tactics of lesbian, gay, bisexual, and trans (LGBT) interlocutors navigating al-wad' (the situation), a nebulous term that refers to the normative order of disruptions, precarity, and instability that permeate daily life across contemporary Beirut. For Moussawi, al-wad' simultaneously features as a historical condition of "imminent disruption" bearing on daily life in Beirut, as well as an analytical lens to unpack the everyday strategies used to navigate these 
disruptions (3). Through a grounded, inductive approach to these daily practices, Moussawi shows how LGBT interlocutors inhabit multiple, fluid positionalities that are always changing relative to al-wad'. Moussawi lingers on these ambiguities as part of the effort to reimagine notions of queerness, subjectivity, and politics.

Moussawi's focus on daily practices is motivated by a critique of exceptionalist representations of Beirut and LGBT experiences there through the conceptual tool of "fractal orientalism." In contrast to the monolithic categories rendered through Edward Said's notion of the orient and occident, 1 fractal orientalism is a relational construct of "nested binaries" that produces hierarchies and exclusions based on geographic associations that operate transnationally, regionally, nationally, and locally among the neighborhoods of Beirut (37). A well-trodden transnational example fashions Beirut as the "Paris of the Middle East," which appends exceptional qualities to Beirut by excising the city from its regional surroundings. The associations of Beirut with Paris assert notions of a "modern," "cosmopolitan" European-like city that is not quite European, but also unlike cities across the Middle East (11). Moussawi's intervention departs from fixed and reductive binary representations of East-West that defined classic orientalism by accounting for how the relational narratives of fractal orientalism obfuscate local political economies of gender and sexuality within Beirut. For Moussawi, fractal orientalist representations of the "openness" of Beirut elide local struggles faced by the most vulnerable populations based on race, class, gender, sexuality, or citizenship status (examples of the latter include Syrians, migrant workers, or Palestinian refugees).

Disruptive Situations is organized according to the intertwined aims of critiquing exclusionary representations, and analyzing queer tactics and strategies of daily life in Beirut. The text includes five chapters. Chapters 1 and 2 introduce and show the pervasiveness of fractal orientalism, whereas chapters 3-5 map the different queer strategies and tactics of Moussawi's LGBT interlocutors.

Chapters 1 and 2 critique the proliferation of fractal orientalism in transnational and local representations of and within Beirut. Whereas the racialized, sexualized, and gendered logics of transnational fractal orientalist representations of Beirut gloss over the effects of racism, sexism, and sectarian divisions, Moussawi details how LGBT interlocutors respond by variously contesting and reproducing fractal orientalism. For example, interlocutors describe being shamed based on markers of class status such as insufficient English or French proficiency that uphold the "global imaginings of what constitutes gay-friendly spaces and people" (33). Alternatively, one of Moussawi's interlocutors strategically gender identified as a female at military checkpoints so as to avoid inappropriate touching by soldiers. By highlighting the limitations within fractal orientalist representations of Beirut, Moussawi advances the need for a grounded approach that details how LGBT interlocutors contest and rework fractal orientalism.

Moussawi emphasizes relationality in his inductive analysis of the everyday strategic use of identities, visibility, and sources of solace from al-wad' in chapters 3-5. Rather than "reconcile" what are assumed to be coherent, mutually-exclusive identities (e.g., Muslim or Christian and gay), Moussawi's LGBT interlocutors decenter static universalized European-American LGBT subjectivities of "closeted" or "out" through the adaptations of identities to the fluid conditions of al-wad'. Here, the interlocutors "embrace and make use of seeming contradictions in their lives" by continually negotiating what to make visible, to whom, and under what circumstances (102). These relational practices 
challenge the notion of fixed identities that "rely on flattened understandings of queerness, religion, and culture" (102). This strategic renegotiation of essentialized, static gender and sexuality categories challenges the very premise of the visibility at the core of fractal orientalist representations of LGBT experiences in Beirut. Moussawi's interlocutors employ relational visibilities, such as "signaling" sexuality to others without explicitly stating it, based on vulnerabilities and senses of safety (119). Or they suspend al-wad' through "bubbles," temporal spaces of solace for kinship, solidarity, and support. These bubbles constitute spaces of community based on a multiplicity of identities that embrace political alignments, such as Palestinian solidarity-or even linguistic connections to speak Armenian-rather than spaces exclusive to expressions of gender or sexual identities.Moussawi's deft analysis dismantles the exclusionary logics in representations of LGBT experiences in Beirut. However, the text is sharpest when weaving together the embodied experiences of LGBT interlocutors who resist and renegotiate the terms of intelligibility imposed by neoliberal interpretations of "appropriate queerness" (71). Disruptive Situations will have wide appeal across queer and sexuality studies, queer theory, urban studies, sociology, postcolonial theory (or more broadly colonial studies), and Middle East studies. Scholars will glean valuable theoretical tools that enable the reworking of conceptual limitations across disciplines. While Moussawi concludes that the queer strategies and tactics of the LGBT interlocutors have purchase across the Global South, these everday strategies of navigating al-wad' find resonance with the everyday strategies of navigating the sedimented histories of anti-Black and homophobic violence that pervade the institutions and streets of Louisville as much as in London or Cairo. Indeed, considering the current moment of COVID-19, ongoing racial and homophobic violence, and the corruption that led to Beirut's August 4, 2020 explosion, Moussawi's intervention feels both prescient and urgent.

\section{Notes}

1. Edward Said, Orientalism (New York: Pantheon Books, 1978).

\section{Author Information}

\section{Robert Flahive}

Robert Flahive is a PhD Candidate in the Alliance for Social, Political, Ethical, and Cultural Thought (ASPECT) program at Virginia Tech. His research explores the preservation of architecture and spaces produced through twentieth-century colonialism in Casablanca, Tel Aviv, and Addis Ababa. He is interested in the intersections of urbanism, architectural theory, history, historic preservation, and international politics. He holds an MA from the American University of Beirut and a BA from Washington University in St. Louis.

View all of Robert Flahive's articles. 


\section{Article details}

Robert Flahive, "Review of Disruptive Situations: Fractal Orientalism and Queer Strategies in Beirut by Ghassan Moussawi (Temple University Press)," Lateral 10.1 (2021).

https://doi.org/10.25158/L10.1.29

This content is licensed under a Creative Commons Attribution-NonCommercial 4.0 International License. Copyright is retained by authors.

Lateral is the peer-reviewed, open access journal of the Cultural Studies Association.

ISSN 2469-4053 